\title{
Powertrain technology transfer between $F 1$ and the automotive industry based on Mercedes-Benz
}

The paper presents evolution of the Formula One powertrain systems and its synergies with the Automotive industry. The article emphasises the influence of trends in the Automotive industry and general environmental awareness on the Formula One development. The technical regulations introduced by the FIA in 2006 made a first steps to align Formula One technology progress with course of automotive world. Improvements of the regulations in 2009 and 2014, gradually introduced hybrid systems to the Formula One and made its technology more relevant to the current production vehicles. On the other hand, paper also shows the examples of the automotive projects which utilised Formula One technology features and qualities. This review analyses technology transfer based on Mercedes-Benz and other companies dependent on Daimler AG.

Key words: Formula One, hybrid technology, powertrain systems, technology transfer, automotive industry

\section{Introduction}

Since the motor vehicle has been invented, a continuous race to be the best has started among automobile manufacturers and engineers. Motorsport seems to become one of the most popular ways to assess the construction of the vehicle and distinguish the best designs among different competitors. The first motor race took place in 1894 on the route between Paris and Rouen and highly stimulated various motor vehicles enthusiasts, engineers, manufacturers and entrepreneurs. The competition between automobile manufacturers and all different organisations involved into automobilism caused significant development in most of the automotive related fields of science. Within internal combustion engines (ICE) widely understood areas of physics, for instance: mechanics, thermodynamics or material technology have been hugely expanded. Internal combustion engines have always been the most important and the most complex part of powertrain systems. In the $20^{\text {th }}$ century rapid development of this areas of the automotive indus- try brought increased diversification of engines and vehicles making them more specialised. Obviously since then, not all the purpose-made engines and vehicles were useful for motorsport or racing. Following that trend, racing engineering took its own path as well and since then have not always been relevant to the technology of "everyday" vehicles $[4,5]$.

Formula One (F1) is a great example of purpose-built engines and vehicles exclusively for motorsport. Major trend in development of F1 engines has been always their performance, specifically their maximum effective power within narrow band of speed range against the engine speed of the maximum power [6]. This established a specific direction of development for these engines as well as powertrain systems and differed substantially from common vehicle applications for many years. Fig. 1 presents Mercedes' engines specific power (maximum power related to $1000 \mathrm{~cm}^{3}$ of engine displacement) and ICE thermal efficiency through last over 25 years.

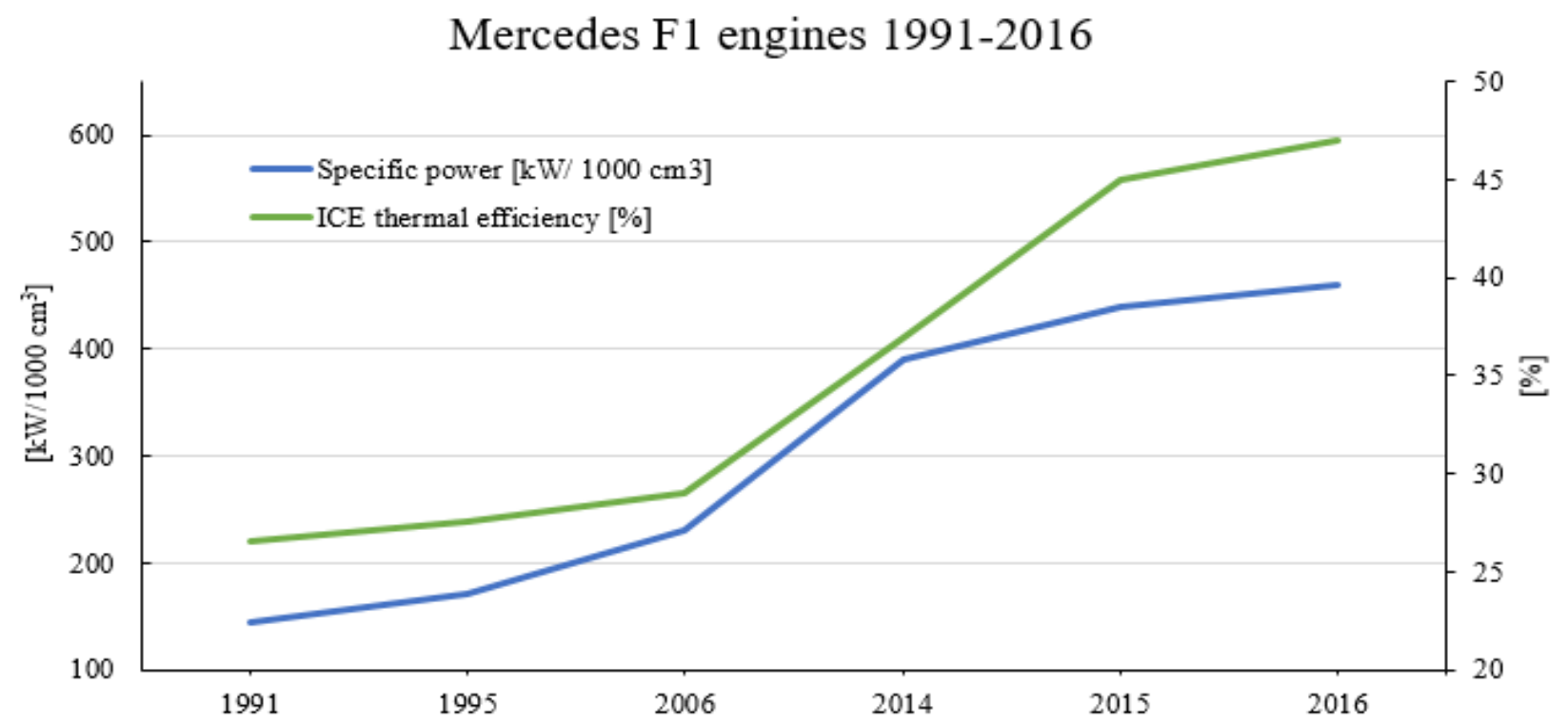

Fig. 1. Specific peak power and ICE thermal efficiency for Mercedes F1 engines between 1991-2016 
In the $21^{\text {st }}$ century, the situation within F1 and the automotive industry has begun to change. The governing body of the F1, the Federation Internationale de l'Automobile (FIA) started to introduce important changes to the F1 Technical Regulations. From 2006 cost reduction, increase in engine reliability and safety have been thoroughly considered. In 2009, then more widely in 2014, hybrid systems have been introduced to $\mathrm{F} 1$ as a response to the current trends in the automotive industry. Further reliability improvements, cost reductions and engine efficiency enhancements were also required. The steps undertaken in the first decade of the $21^{\text {st }}$ century within the F1 regulations to improve technology alignment between F1 and the automotive industry have already brought satisfactory effects. Fig. 2 shows Mercedes' development timeline within over 10 last years, where F1 and Automotive industry transfer was included.

\section{History of Mercedes-Benz in Formula One}

From the very beginning of motorsport racing history, Mercedes-Benz has always been involved. This even includes the first motor race Paris-Rouen in 1894 where Emile Roger finished the race on in 14th position with his Benz vehicle. From 1923, Benz was widely involved in motor racing. In the 1930s, the legendary name "Silver Arrows" became famous because of Mercedes' cars domination [22, 23].

\subsection{Mercedes-Benz in Formula One racing 1954-1955}

Mercedes-Benz debuted in Formula One in 1954, four years after the F1 World Championship was established in 1950. The racing team managed by Alfred Neubauer had immediate success with driver Juan Manuel Fangio winning the Drivers' Championship in the first year. The success continued through entire next season with Fangio winning the Drivers' Championship again in 1955. In these seasons the name 'Silver Arrows' was already applied to the winning cars. This emphasized the team's connection to the famous Mercedes-Benz "Silver Arrow" cars dominating Grand Prix racing in Europe between 1934 and 1939 [22, 23].

The cars used in the 1954 and 1955 seasons were technologically advanced and named the Mercedes-Benz W 196 shown on Fig. 3. They were produced in two body versions: open-wheel (monoposto) and streamlined, closed-wheel. The body was made of magnesium-alloy panels built over a lightweight tubular spaceframe. Cars were also equipped with drum brakes and suspension with torsion bars.

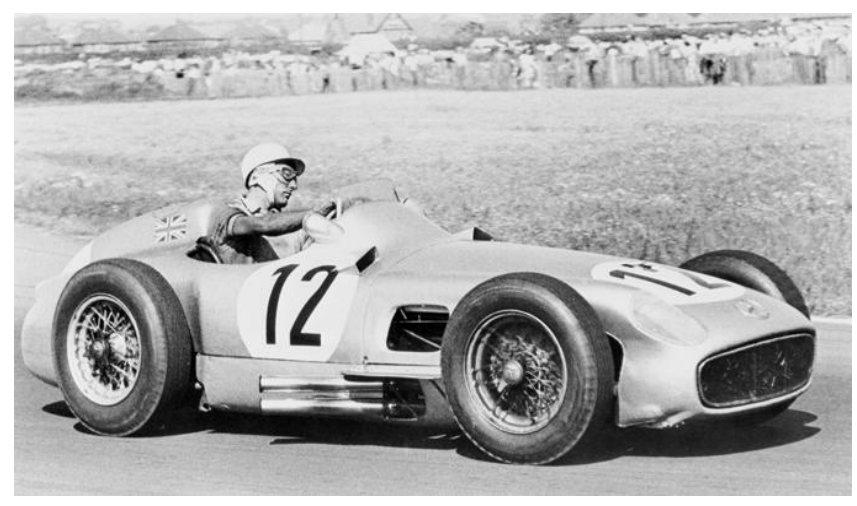

Fig. 3. Mercedes-Benz W 196 „Silver Arrow” from 1995 [22]

According to the sport's governing body the Commission Sportive Internationale, new rules released in 1954 allowed either $2500 \mathrm{~cm}^{3}$ naturally aspirated or $750 \mathrm{~cm}^{3}$ would not be effective enough and a decision was made to create a new one. The newly designed engine was a straight eight, $2497 \mathrm{~cm}^{3}$, naturally aspirated engine. It was mounted supercharged engines to be used in Formula One. Taking

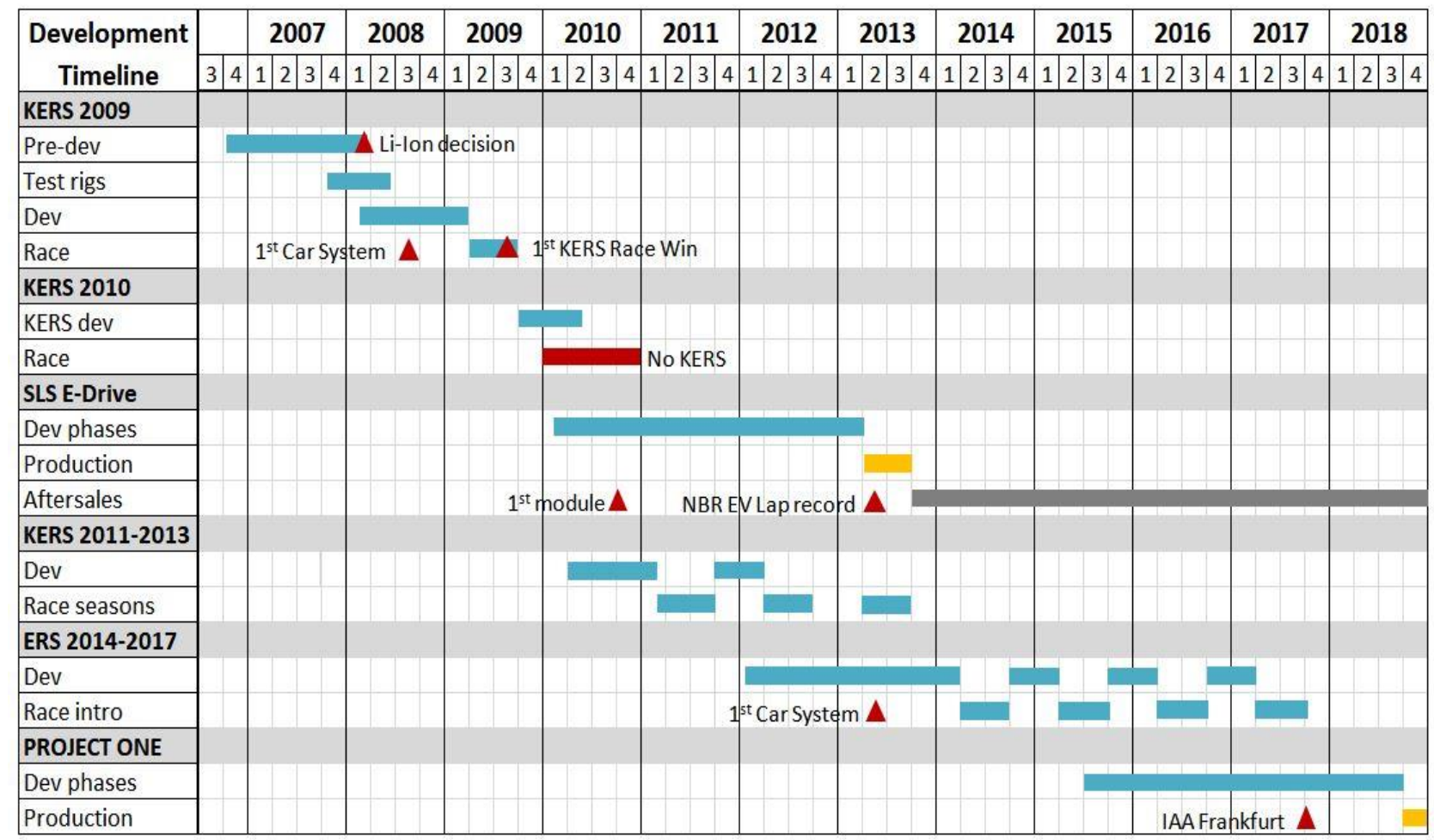

Fig. 2. Development timeline of hybrid systems and F1-related automotive projects in Mercedes-Benz 
new rules into account Mercedes started extensive studies on their existing supercharged, $1500 \mathrm{~cm}^{3}, \mathrm{~V} 8$ engines from 1939. Calculations showed that a redesign of the old engine at an angle of 53 degree to the vertical axis to lower the center of the gravity and reduce the frontal area. The most important feature of this construction was a direct fuel injection developed together with Bosch which gave a significant advantage to the carbureted engines. The W 196 engine was also equipped with desmodromic valves which allowed the engine speed to exceed $8000 \mathrm{rpm}$ and for bigger valves to be used without spring failure. The engine delivered $188 \mathrm{~kW}$ at $8260 \mathrm{rpm}$ in 1954 and $213 \mathrm{~kW}$ at 8500 rpm in 1955 [22, 23].

The W196 was also used as the basis for the MercedesBenz to win the 1955 World Sportscar Championship, with the Mercedes-Benz 300 SLR. Mercedes dominated the 1955 Championship, until a catastrophic crash at Le Mans in June. Despite winning the Formula One World Championship in 1954 and 1955, as well as leading the World Sportscar Championship, Mercedes decided to withdraw from the all forms of a motorsport with immediate effect.

\subsection{Mercedes-Benz as an engine supplier 1994-2005}

Changes introduced to the Formula One technical regulations in 1989 completely ended the "turbo era" as new regulations allowed only $3500 \mathrm{~cm}^{3}$, naturally aspirated engines, up to 12 cylinders. Since then turbocharging was forbidden completely in F1. On this occasion Ilmor, the company founded in 1983 by former Cosworth engineers following their successful period with IndyCar engines debuted in Formula One in 1991. They supplied the new LH10 engines for Leyton House, March and Tyrrell Formula One teams during 1991 and 1992 seasons. Ilmor LH10 was a V10, $3498 \mathrm{~cm}^{3}$ engine generating $507 \mathrm{~kW}$ at 13000 rpm in 1991 and $522 \mathrm{~kW}$ at $13300 \mathrm{rpm}$ in 1992 [12].

Mercedes-Benz planned to re-enter the Formula One in 1991 with Sauber as a partner, but then suspended the decision in 1992. Eventually during 1993 Mercedes-Benz took the observational role over Sauber Team and formed partnership with Ilmor. During that season "Concept by Mercedes-Benz" were written on the Sauber' engines produced by Ilmor.

Mercedes-Benz officially returned to Formula One as an engine supplier in 1994, entering the season as SauberMercedes team. Mercedes provided updated and rebadged "Powered by Mercedes-Benz" version of Ilmor's engine from the previous season for Peter Sauber's Formula One team. The same year, Daimler-Benz AG (Mercedes parent company) acquired $25 \%$ of Ilmor's shares from Chevrolet consolidating their influence on the company.

For the 1995 season, significant changes to the Formula Ones technical rules were made. Due to the new regulations engines need to be naturally aspirated with displacement decreased to $3000 \mathrm{~cm}^{3}$ and maximum of 12 cylinders. There was no limit on engine rpm. For this season Mercedes formed a partnership with McLaren and prepared the new FO 110 engine internally known as FH shown on Fig. 4. It was a $2997 \mathrm{~cm}^{3}, \mathrm{~V} 10$ with peak power of $515 \mathrm{~kW}$ at $15600 \mathrm{rpm}$.

McLaren-Mercedes won the opening race of the 1997 season which was the first Mercedes-badged engine win.
The following season brought both the Drivers' and Constructors' Championship with Mika Hakkinen at the wheel. Mika also went on to win the Drivers' Championship in 1999. DaimlerChrysler AG increased Mercedes-Benz' shares in Ilmor up to 55\% in 2002 and renamed the outfit Mercedes-Ilmor. In 2005 DaimlerChrysler AG became the sole owner of Ilmor and renamed the company MercedesBenz High Performance Engines.

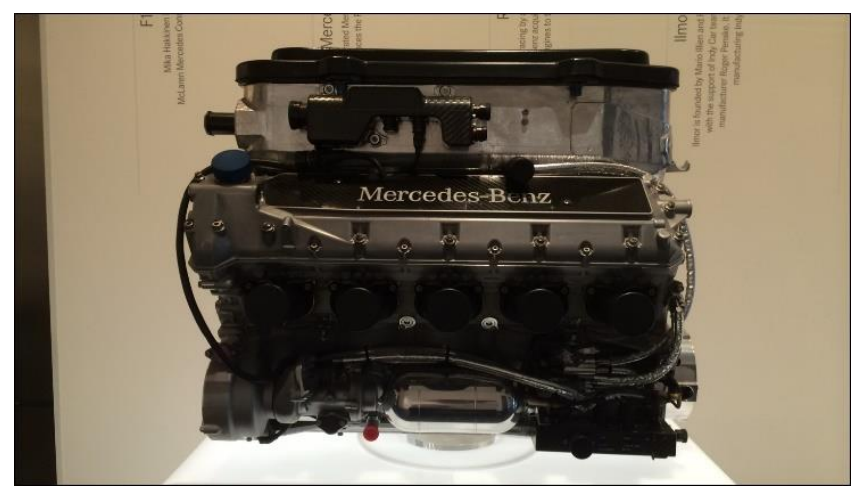

Fig. 4. Mercedes-Benz Fo 110, $3000 \mathrm{~cm}^{3}$, V10 engine for $1995 \mathrm{~F} 1$ season

The new FIA technical regulations for 2005 limited the maximum number of engine cylinders to 10 and no more than 5 valves per one cylinder were allowed. For that season Mercedes came prepared with its last V10 engine marked FO 110R for McLaren [13].

\section{First hybrid system in Mercedes - KERS (limi- ted technology transfer)}

Significant amendments were made for the 2006 season to the Formula One technical regulations. Explicit actions were also undertaken to reduce costs and increasing speeds on the Formula One cars.

\subsection{Introduction of $\mathrm{V8}$ engines}

The most important changes were introduced to the engine specification. It had to be four stroke engine with displacement of no more than $2400 \mathrm{~cm}^{3}$ which is $20 \%$ less than in previous regulations. The engine was arranged as a V8 with a 90 degree angle between the banks. Similarly to the previous rules, from the 2006, an engine remained naturally aspirated although for the first time an engine layout and cylinders number were given. Change from any V10 to V8 with restricted 90 degree bank angle resulted in use of single plain crankshaft which associated higher vibrations than in previous V10 engines.

Only 2 circular inlet and exhaust valves were permitted. Previous attempts to introduce 5 valves per cylinder have not been considered as increased valve area did not compensate negative impact on combustion chamber shape. Pneumatic Valve Return Systems (PVRS) and sodium cooled valves were still legal. Higher torsional vibration than in V10 on a timing system gear drive also required use of camshaft dampers. The maximum bore diameter was established as $98 \mathrm{~mm}$ which limits the stroke to be 39.79 $\mathrm{mm}$ at maximum bore. Spacing between the cylinders was set at $106.5 \mathrm{~mm}$. The revolution limit remained unrestricted for 2006. This allowed Mercedes' development engine to 
obtain more than $20000 \mathrm{rpm}$ which with given stroke results with mean piston speed $\left(\mathrm{S}_{\mathrm{p}}\right)$ over $26.5 \mathrm{~m} / \mathrm{s}$ [1].

The use of variable inlet or exhaust geometry was not permitted and variable valve timing and variable valve lift were also banned. Indirect fuel injection was permitted only with one injector per corresponding inlet port with fuel pressure which does not exceed $10 \mathrm{MPa}$. Multiple injectors were no longer legal although increased fuel pressure allowed better atomization. Similarly, in terms of ignition, only one spark plug and spark coil per cylinder was allowed. The minimum weight of the engine was set to $95 \mathrm{~kg}$.

The new rules placed a lot of emphasis on the reduction of engine development costs, specifically limiting the materials which could be used within an engine. Crankcases, cylinder heads and pistons could be manufactured only from aluminum alloys. Crankshaft and camshafts could be manufactured only form iron based alloys. Nitriding and Diamond Like Carbon (DLC) treatments were still permitted. Since 2006, no materials with density higher than 19 $000 \mathrm{~kg} / \mathrm{m}^{3}$ were allowed to be assemble with the crankshaft which disqualified pure tungsten although tungsten alloys were still legal. Magnesium based alloys, Intermetallic materials and Metal Matrix Composites (MMC's) were forbidden. All materials containing more than $5 \%$ by weight of Beryllium, Iridium and Rhenium were also banned [10, 14].

Further cost reductions froze the engine specification and put more pressure on increasing of reliability. Engine revolution limit at $19000 \mathrm{rpm}$ was set from 2007. Since 2008 engines must last for at least four race weekends [15, 16]. Reduction of engine displacement decreased the maximum power output of about $20 \%$ in comparison to the previous engine specification, but also reduced fuel consumption up to $15 \%$. Teams which could not afford to obtain new engines were allowed to use previous, 2005 season ones with adequate revolution limitations [9].

For 2006 season Mercedes-Benz presented a very well prepared, powerful and reliable FO $108 \mathrm{~S}$ engine presented on Fig. 3. It generated over $555 \mathrm{~kW}$ of peak power at $19000 \mathrm{rpm}$ with break mean effective pressure (BMEP) over 14.6 bar [18]. In 2007 FO108T, an updated version

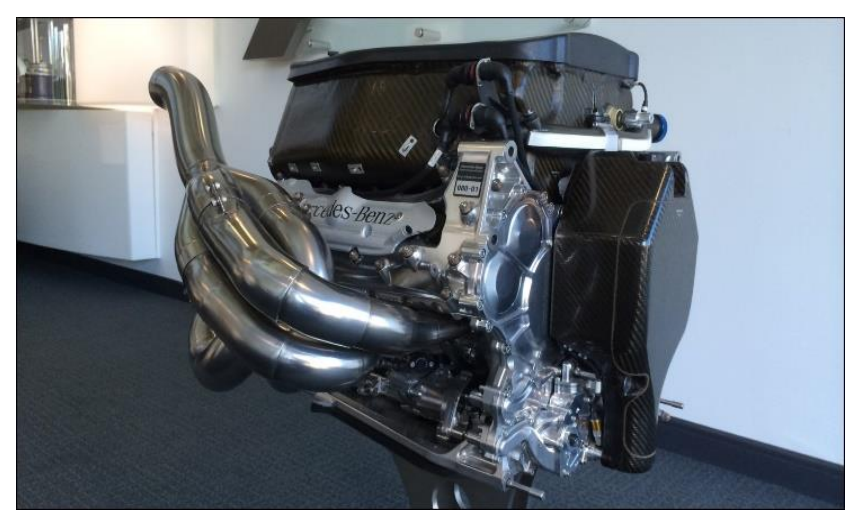

Fig. 3. Mercedes-Benz FO 108 S, $2400 \mathrm{~cm}^{3}$, V8 for 2006 F1 season

of the 2006 season engine powered Lewis Hamilton and Fernando Alonso driving for the Vodafone McLarenMercedes team to eight pole positions and eight race wins. This engine also achieved a great result of zero race week- end failures over 32 races that season. In 2008 season, Lewis Hamilton won his first Drivers' Championship with Mercedes' engine powered car.

\subsection{KERS introduced to the V8 engines}

A continuation of the FIA's cost reduction policy from 2006 aligned with improvements in engine reliability was expanded in the next few seasons. In 2009, the FIA allowed the use of KERS (Kinetic Energy Recovery System) in Formula One and restricted engine revolutions even further - to $18000 \mathrm{rpm}$. An enhancements in engine reliability was forced by the introduction of the requirement that only 8 engines could be used by a driver over a single season. KERS allows energy to be harvested during braking, stored and then deployed by the driver's decision at any point during the race, e.g. during overtaking. That explains why in some circumstances KERS might be call a regenerative braking. According to the 2009 the FIA regulations, KERS in Formula One could release no more than $400 \mathrm{~kJ}$ of recovered kinetic energy in any one lap. Rules also allow the transfer of no more than $60 \mathrm{~kW}$ of energy in and out of the KERS. Mercedes-Benz started their work on KERS in 2007, shortly after the first season with new, V8 specification engine was finished. No restrictions to the KERS technology was applied therefore different solutions were considered. Mercedes-Benz prepared three systems: flywheel, lithium-ion (Li-Ion) battery and ultracapacitor [17, 18].

Electrical KERS with motor-generator and battery was chosen (Fig.6). Battery with Li-Ion cells were developed as it has the highest energy density by mass in comparison to other electrochemical cells. In this solution, motorgenerator was mechanically coupled with ICE crankshaft by fix speed ratio creating integrated hybrid system [2, 3]. The first fully operational test module was introduced in only 8 months. Tests of the new system started at the beginning of 2008, only 14 months after the pre-development stage.

Mercedes' first F1 hybrid engine unit was the FO 108W which was an improved 2008 season engine with electric

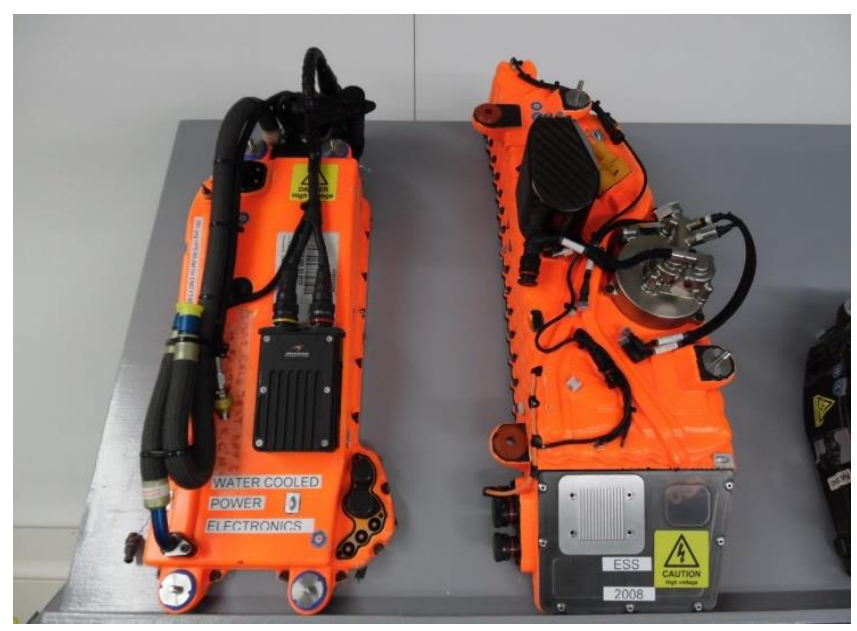

Fig. 4. First track test KERS battery and power electronics from 2008

motor-generator, lithium-ion battery and power electronics, internally known as FW. It generated over $555 \mathrm{~kW}$ of power at $18000 \mathrm{rpm}$ with an oil cooled battery pack and total 
KERS mass of $25.3 \mathrm{~kg}$ (Fig. 7). Efforts of Mercedes' engineers resulted in the first win of a KERS powered carVodafone McLaren-Mercedes during the 2009 Hungarian Grand Prix.

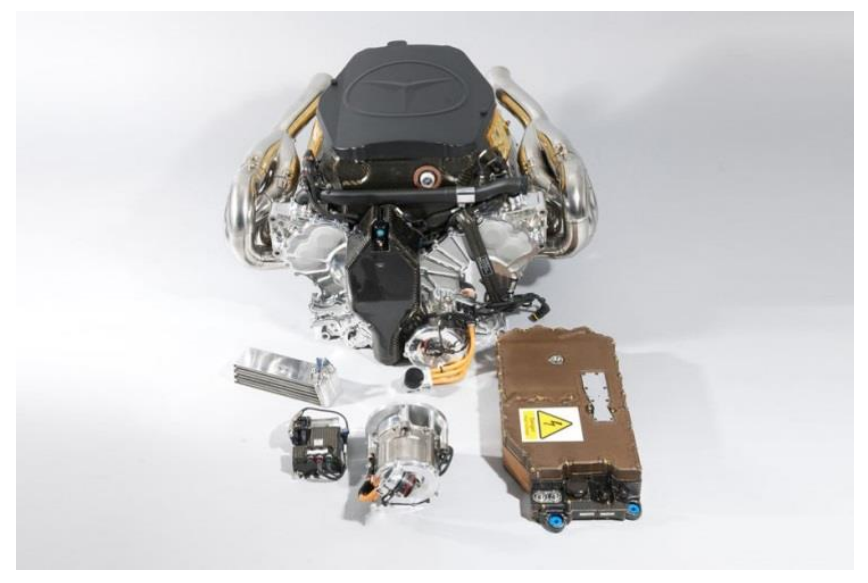

Fig. 5. Mercedes-Benz FO $108 \mathrm{~W}, 2400 \mathrm{~cm}^{3}$, V8 with KERS for $2009 \mathrm{~F} 1$ season [25]

Later in 2009 Mercedes-Benz bought a controlling stake $(75.1 \%)$ of the championship winning Brawn GP, renamed it Mercedes GP one year later and signed a sponsorship agreement with Petronas. In 2010 Mercedes GP Petronas Formula One Team drove with their „Silver Arrows” again after 55 years. KERS was still legal this year however all Formula One teams agreed not to use it. It returned to Formula One in 2011 at which point Mercedes-Benz High Performance Engines factory was renamed Mercedes AMG High Performance Powertrains. KERS was used in that form in F1 until 2013.

\section{Advanced hybrid systems - ERS (improved technology transfer)}

Technological changes introduced by the FIA in 2006 and then in 2009 explored new opportunities within powertrain technology in Formula One. Engines became more efficient, reliable and cheaper in development. Utilising KERS as a first hybrid technology also emphasised its relevance to current trends in the automotive industry and paved a new way in F1 powertrains. In 2010 the FIA decided to take the next step and expand technology alignment between $\mathrm{F} 1$ and automotive industry even further.

\subsection{Changes in Technical Regulations}

From 2010 the FIA started to work on new technical regulations. They wanted to attract more sponsors and vehicle manufacturers to invest in F1 by offering them a proving ground for technology development. New technical regulations which were subject to apply from 2013 included more factors affecting current automotive powertrain systems. Significant increase of thermal efficiency, downsizing and advanced hybridisation were considered. General environmental aspects, such as $\mathrm{CO}_{2}$ reduction were also taken into account together with further enhancement of reliability. The first draft of the new technical regulations introduced a $1600 \mathrm{~cm}^{3}$, four cylinder turbocharged engines with fuel flow rate restrictions and energy recovery systems. The provisional regulations came across major protests, which influenced the rules and postponed its introduction.

Finally, the new rules became valid from 2014 and launched a new turbocharged V6, hybrid power unit formula with a displacement of $1600 \mathrm{~cm}^{3}$. It was a serious turn in Formula One history. The technical term- engine, was no longer applicable and changed in favour of advanced hybrid power unit. From then, power output was calculated as a combined value of the mechanical energy from the internal combustion engine based on its thermal efficiency and the electrical energy from energy recovery system (ERS). Since the new rules reduced the internal combustion engine displacement by a third in comparison to the V8, the maximum power output decreased significantly. I addition to that new requirements assumed use of direct fuel injection and maximum fuel flow rate of $100 \mathrm{~kg} / \mathrm{h}$. Following these restrictions, a decision was made to establish the maximum power of the electric motor assisting ICE (MGUK) at level of $120 \mathrm{~kW}$, which is double the value of its predecessor KERS [19].

In term of material that could be used for PU, the FIA applied further restrictions to the previous rules from 2006. Since 2014, no tungsten alloys are permitted to be used at all, as well as ceramics and ceramics matrix composites. All alloys are restricted to maximum $0.25 \%$ content of beryllium, excluding copper alloys which can contain $2.75 \%$ of berylium. Copper-beryllium alloys were widely used for e.g. valve seats. Minimum weight of the PU must be a minimum of $145 \mathrm{~kg}$ which is $50 \mathrm{~kg}$ more that for previous $\mathrm{V} 8$ engines and allow additional weight for e.g. electric machines.

From 2014 onwards, system of tokens was introduced as a second factor besides finance to maintain costs reduction in powertrain development among different manufacturers. Power Units are broken down into 66 tokens with „weight" from 1 to 3 assigned to different power unit components. Development of certain component uses its tokens therefore manufacturers have to chose what to develop in subsequent years to keep the sustainable PU development.

\subsection{Power Unit (PU) components and its operational modes}

The Power Unit (PU) is a complex combination of internal combustion engine (ICE) and advanced energy recovery system (ERS). From the very beginning it was designed and developed as a sophisticated hybrid machine, significantly different to the previous $2400 \mathrm{~cm}^{3}$, V8 engine with KERS. Having said that in order distinguish the most important parts the Power Unit is divided into 6 subsystems.

\section{Internal combustion engine (ICE)}

As per Formula One Technical Regulations introduced in 2014, internal combustion engine as a part of power unit must be a V6, turbocharged engine with 90 degrees bank angle and displacement of $1600 \mathrm{~cm}^{3}$ at maximum.

Two inlet and two exhaust valves are required with no variable valve lift profile or timing employed. Exhaust gases may exit the cylinders only from the outside of the engine, no from the inside of the "V" arrangement. Valves stem size cannot be smaller than $5 \mathrm{~mm}$. 
Engine revolutions are limited to $15000 \mathrm{rpm}$ therefore lower than the latest amendment for V8 engines in 2013 (18 $000 \mathrm{rpm})$. Allowed maximum cylinder bore is $80 \mathrm{~mm}(18 \%$ less than in $2400 \mathrm{~cm}^{3}$, V8) which implies $53.05 \mathrm{~mm}$ of stroke. Having said that, the mean piston speed $\left(\mathrm{S}_{\mathrm{p}}\right)$ in new V6 engine increased, and again exceeded $26.5 \mathrm{~m} / \mathrm{s}$ as it was in the V8 engine from 2006 when reaching $20000 \mathrm{rpm}$. Stroke-bore ratio also increased from 0.4 in V8 engines to approximately $0.6-0.7$ in new power units. There is no fixed spacing between cylinders required as it was for V8 although the crankshaft may have only 3 connecting rods bearing journals.

The new regulations also introduced more complex fuel restrictions in comparison to the previous V8 rules introduced in 2010. Global maximum fuel flow allowed is 100 $\mathrm{kg} / \mathrm{h}$ (about $35-40 \%$ less than for V8) although up to 10 $500 \mathrm{rpm}$ maximum fuel flow is restricted by following formula: $\mathrm{Q}_{\mathrm{m}}=0.009 \mathrm{n}[\mathrm{rpm}]+5.5[\mathrm{~kg} / \mathrm{h}]$. The amount of fuel that can be used during one race is also restricted to a maximum of $100 \mathrm{~kg}$. Fuel needs to be delivered to the cylinder by a direct injection system. The permitted pressure of fuel that can be supplied to the injectors increased to 50 $\mathrm{MPa}$. In previous V8 engines, fuel pressure only up to 10 $\mathrm{MPa}$ was allowed which made direct injection simply unfeasible to use. The fuel flow rate with V8 engines was usually reaching over $150 \mathrm{~kg} / \mathrm{h}$. One fuel injector per cylinder is allowed as well as one single ignition coil and one single spark plug [8]. Since restrictions about total amount of fuel that can be used in one race is not a new requirement following fuel rules from 2010, the fixed maximal fuel flow restricted is absolutely new. As a result of that, fundamentally new approach to the air excess ratio $(\lambda)$ has been applied [1]. In new V6 engines air excess ratio might exceed 1.2 whereas in previous V8 was usually below 0.8 for the regions of maximum power. Having said that running less rich in case of saving fuel in V6 engines is not that feasible as it was in V8 engines without power loses [7].

\section{Turbocharger (TC)}

In 2014 turbocharging became allowed in Formula One again first time since 1988 [11]. According to the new rules compressing of air needs to be utilised with a single stage compressor joined to the single stage turbine. Both shafts need to rotate about common axis and with the same angular velocity. Charging pressure is not restricted however variable turbine geometry (VGT) is not permitted. The device responsible for recovering energy from heat, the MGU-H, can be coupled directly to the turbine. Rotational speed of the turbine shaft is restricted to $125000 \mathrm{rpm}$.

\section{Motor Generator Unit-Kinetic (MGU-K)}

The MGU-K is an electric machine which can operate as a motor or alternatively as a generator depending on requirement. It is the sole successor of the KERS motorgenerator introduced for the first time in 2009. Restrictions to the maximum power of the MGU-K rise to $120 \mathrm{~kW}$ in comparison to KERS's $60 \mathrm{~kW}$. The maximum torque generated by the MGU-K cannot exceed $200 \mathrm{Nm}$ at any point.

Only one single MGU-K is permitted to recover energy from the vehicle. It needs to be mechanically and perma- nently linked to the ICE crankshaft before the main clutch. A fixed speed ratio between the MGU-K and the ICE is required and might be clutched. The rotational speed of the MGU-K is restricted to $50000 \mathrm{rpm}$.

The MGU-K is the second device after ICE, allowed to propel the vehicle. It acts as an electric motor and assists the ICE during acceleration using energy from energy store (ES) or directly from corresponding device (MGU-H), recovering energy from exhaust gases. During braking, the MGU-K switches to generator mode and assists brake, harvesting part of the kinetic energy that otherwise would be dissipated as heat [7, 19].

\section{Motor Generator Unit-Heat (MGU-H)}

Similarly to the kinetic energy recovery unit, MGU-H is a motor-generator electrical device. It needs to be mechanically connected to the turbine of the pressure charging system. The mechanical connection might be clutched although it must be a fixed speed ratio to the turbine shaft. The maximal allowed rotational speed cannot exceed $125000 \mathrm{rpm}$. Unlike to the MGU-K, power and torque transferred from and to the MGU-H is not restricted.

Acting as a generator, MGU-H harvests the excessive heat energy from the exhaust gases flowing through the turbine and transfers it to the energy store (ES) for later use or directly to the MGH-K to propel the car. Another important function of the MGU-H is to control compressor wheel speed in some operational ranges of the ICE so the air delivered into the combustion chamber matches fuel requirements with given air fuel ratio. The generator mode of the MGU-H uses energy from the ES and accelerates the turbine shaft to reduce turbocharger response delay when exhaust gases flow is low.

\section{Energy Store (ES)}

Energy storage of the Energy Recovering System (ERS) is an electric battery which can never exceed a level of 1000 $\mathrm{V}$. It needs to be designed as a single component and be wholly locate within the survival cell. The weight of the ES needs to be maintained between $20 \mathrm{~kg}$ and $25 \mathrm{~kg}$ for an entire assembly. The allowable peak difference between maximum and minimum state of charge (SOC) of the ES at any time when vehicle is on the track cannot exceed $4 \mathrm{MJ}$.

\section{Control Electronics (CE)}

The main task of control electronics is to manage energy transfer between the MGU-K, MGU-H and ES while working together with the ICE. Depending on current powertrain mode, the control electronics, driven by sophisticated software, executes predefined algorithms to fulfil the driver's demand. This includes charging and discharging of teh ES, as well as changing current form among the certain components of ERS.

\section{Operation of Power Unit (PU)}

The Power Unit (PU) consists of a sophisticated ICE and 5 advanced components of ERS. Operation of this complex assembly is based on diverse energy transfer modes among the components of the PU and depends on the chosen strategy (Fig. 8). The F1 vehicle with substantial 

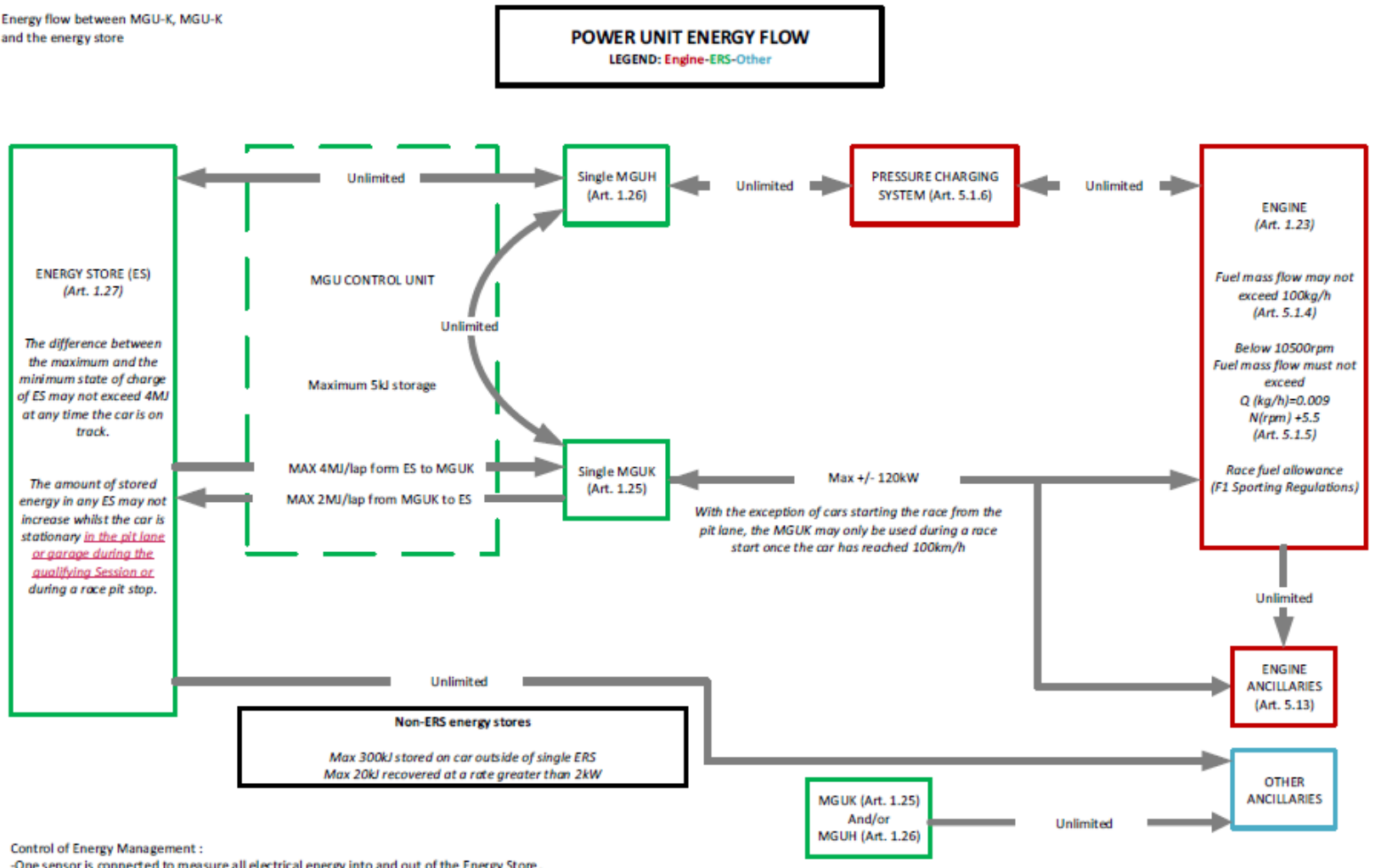

One sensor is $\infty$ nnected to measure all electrical energy into and out of the Energy Store. - One sensor is connected to measure all electrical into and out of the MGU-K.

Fig. 6. Energy flow within Power Unit [20]

speed on a straight line is primarily propelled by ICE using fuel reserves, however additional energy recovered by the MGU-H (generator mode) from excessive amount of exhaust gases might be used by the MGU-K to assist the ICE. During the same event, energy harvested by the MGU-H can be also transferred to the ES for later use. Energy transferred from the MGU-H to the ES and backwards in unrestricted. The same rule applies for energy transferred from the MGU-H to the MGU-K and backwards. When a braking event occurs, the MGU-K works as a generator and assists brake, converting part of the thermal energy from braking into electric energy which can be stored in ES. The maximum amount of energy which can be transferred from the MGU-K to the ES is $2 \mathrm{MJ}$ per lap. Under acceleration after the braking, the MGU-H switches to electric motor mode and propels the turbine shaft to reduce "turbo lag" effect. Additional energy from the ES not exceeding $4 \mathrm{MJ}$ can be deployed to the MGU-K during the same event to support the ICE. It is also worth noting that with the exception of starting from the pit lane, the MGU-K can be used during the race only after the vehicle exceeded $100 \mathrm{~km} / \mathrm{h}$. The F1 vehicle can be also propelled by the ICE only [7, 19].

\subsection{Mercedes's Power Units}

Mercedes AMG High Performance Powertrains, as a part of Mercedes-Benz Formula One team, started its work on a new power unit in 2012 when the new rules regarding $1600 \mathrm{~cm}^{3}$, V6 Power Units became firm. The biggest focus was put on the 4 teams dealing with crucial features of the new Power Unit: combustion simulation, turbocharger design, hybrid system and software development. Absence of supercharging in F1 for the last 25 years at that time led the Mercedes engine development team to search for expertise in parent Daimler company. This resulted with good cooperation with the Mercedes-Benz Trucks division as well as MTU gas turbine group. First development engine, with internal name GB, weighted over $250 \mathrm{~kg}$ and it was not possible to even fit it into a $\mathrm{F} 1$ vehicle. It was not so advanced and sophisticated as the latest ones. A separate turbocharger and MGU-H assembly was also not developed yet at this stage. Nevertheless, this module allowed the engineers to understand the mechanisms of direct injection and charge motion in the cylinder together with gas exchange and combustion. Results of this work were transferred to the single cylinder development engines which allowed goals to be set for the final module for the 2014 season (Fig. 9).

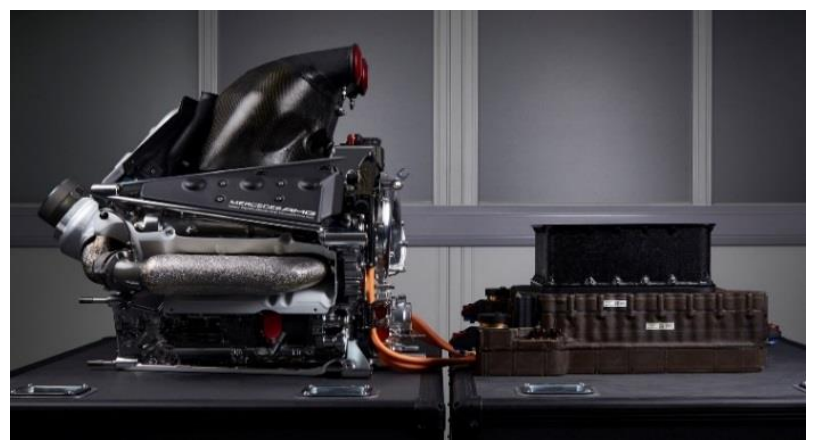

Fig. 7. Mercedes-Benz PU 106 A Hybrid, $1600 \mathrm{~cm}^{3}$, V6 power unit for $2014 \mathrm{~F} 1$ season [25] 
In 2014, PU 106 A Hybrid, internally known as GD, complied with the new F1 Technical Regulations and was introduced into the Mercedes F1 W05 Hybrid vehicle. It was the first Power Unit delivered by Mercedes AMG High Performance Powertrains. It led Lewis Hamilton to win his second Drivers Championship and brought Mercedes the 2014 Constructor Championship. The engine generated over $630 \mathrm{~kW}$ at $15000 \mathrm{rpm}$ at the end of the 2014 season and presented over $37 \%$ of thermal efficiency as a sole ICE.

The 2015 season brought slight changes to the engines specification and sporting rules. The new PU 106 B Hybrid (GE) engine, introduced for this season, presented similar architecture to its previous version although only $5 \%$ of parts were carried over from the last season without modifications. Variable length intake became permitted which was related closely to improvements in engine efficiency but also implicated some packaging challenges with larger plenums. Reliability of the engines had to increase significantly since 4 engines per season per driver were introduced in place of 5 engines in previous season. This implies over $5000 \mathrm{~km}$ of track time. At the end of the 2015 season PU $106 \mathrm{~B}$ Hybrid performed $710 \mathrm{~kW}$ at $15000 \mathrm{rpm}$ and over $45 \%$ of thermal efficiency. Lewis Hamilton won his third Drivers Championship and Mercedes F1 became a Constructors' Champion again [20].

In 2016, PU 106 C Hybrid (Fig. 10) raised the bar even higher establishing the thermal efficiency of the ICE over $47 \%$ and peak power at $750 \mathrm{~kW}(1000 \mathrm{KM})$ at $15000 \mathrm{rpm}$. Moreover, overall efficiency of the PU which is ICE and ERS in 2016 exceeded 50\%. This year, technical rules also included changes in tailpipe design. Separate pipes were permitted to be use from wastegate and turbocharges outlets. The change in regulations was caused by fans' complains that F1 Power Units are too quiet and suppose to make them about 20-25\% lauder. Nico Rosberg won the Drivers' Championship this year and Mercedes celebrated the third Constructor Championship [8, 21].

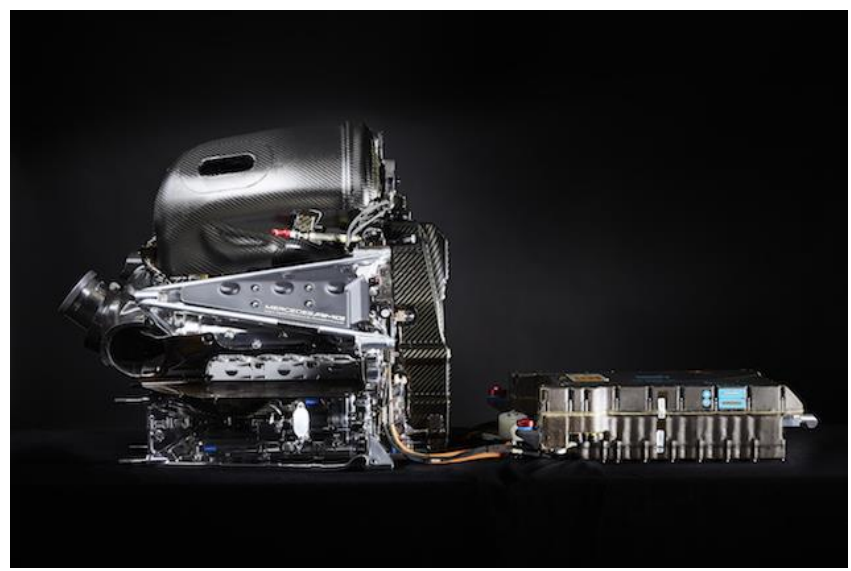

Fig. 8. Mercedes-Benz PU $106 \mathrm{C}$ Hybrid, $1600 \mathrm{~cm}^{3}$, V6 power unit for 2015 F1 season [25]

\section{Technology transfer - examples}

Development of KERS started in Mercedes AMG High Performance Engines in 2007. After first successful season in 2009, KERS was not used for any of F1 teams in 2010, came back in 2011 and it was used for the last time in 2013. Broad expertise in high performance hybrid systems and gap in use of KERS in 2010 was utilised by Mercedes-Benz to develop technologies which can be transferred to the automotive industry.

\subsection{Mercedes-Benz SLS AMG Electric Drive}

Mercedes-Benz SLS AMG Coupe Electric Drive was technically based on the Mercedes-Benz SLS AMG released in 2010 as a successor to the legendary MercedesBenz 300 SL “Gullwing” from 1954. Mercedes-Benz SLS AMG Coupe Electric Drive was developed by MercedesAMG division as its first vehicle designed independently from Mercedes-Benz. The electric powertrain and especially the battery was fundamentally based on knowledge brought from F1 KERS and developed at Mercedes AMG High Performance Engines, from 2011 known as Mercedes AMG High Performance Powertrains. The first prototype vehicle, called the Mercedes-Benz SLS AMG E-CELL, was shown in 2011 in the North American International Auto Show (Fig. 11). The production version was presented in 2012 at the Paris Motor Show and introduced to production in 2013.

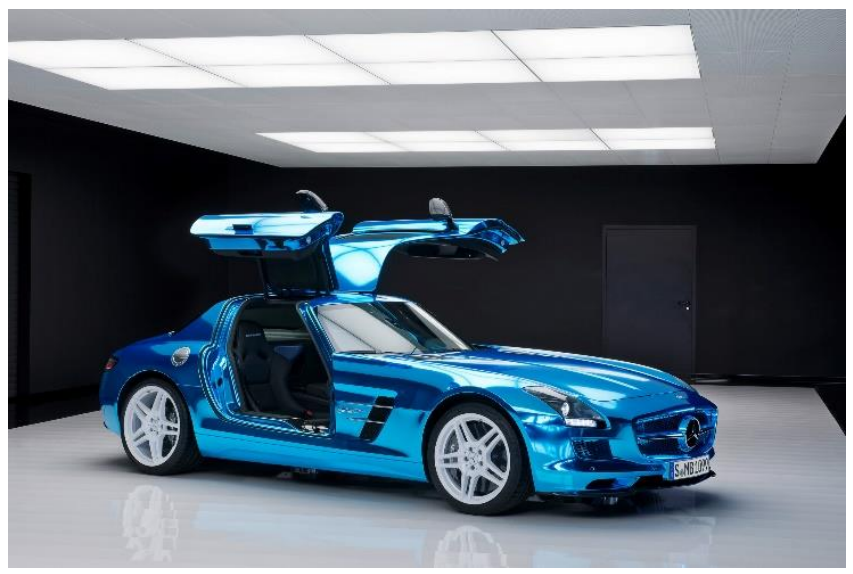

Fig. 9. Mercedes-Benz SLS AMG Electric Drive- vehicle overview [24]

The powertrain of the Mercedes-Benz SLS AMG Coupe Electric Drive was based on four compact permanentmagnet synchronous electric motors. Each of them weighted $45 \mathrm{~kg}$ and were able to achieve $13000 \mathrm{rpm}$. The motors could be driven selectively enabling precise torque distribution. All four motors together generated $552 \mathrm{~kW}$ of power and $1000 \mathrm{Nm}$ of torque. The battery of the vehicle was a liquid-cooled, $400 \mathrm{~V}$ module with energy content of $60 \mathrm{kWh}$. It weighted $548 \mathrm{~kg}$ and contained 12 sections of 72 lithium-ion cells. Those 864 cells were arranged in a parallel circuit of independent modules which allowed efficient space use and enabled battery service. Similarly, as in KERS from F1, the battery can be charged by energy recuperated during vehicle deceleration. The battery module was closed in high-strength aluminium casing within the carbon-fiber reinforced plastic (CFRP) zero intrusion monocoque. This protects the battery from deformation or damage in case of crash event. In addition, battery of the vehicle could be charged at home by $22 \mathrm{~kW}$ device called „wall box" and supplied with the car. Charging lasts about 20 hours.

High performance power electronics covert direct current from the battery module in 3-phase alternating current 
for 4 synchronous electric motors and controls the energy flow within the system under variable operating conditions. The powertrain is also equipped with three low temperature, the cooling circuits, two for electric motors and sepa- rate one for the battery module. Under extremally low ambient temperature cooling systems can switch into warming mode to bring the system to the operational conditions.

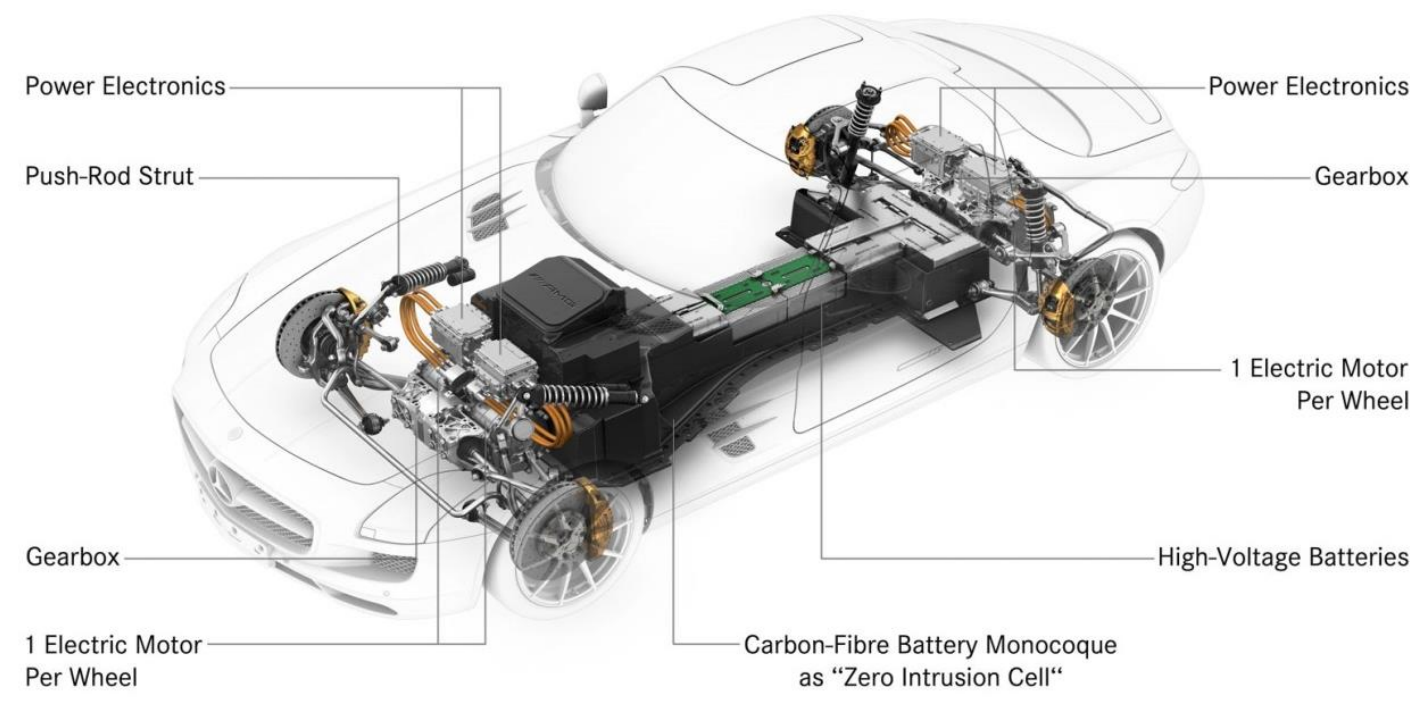

Fig. 10. Mercedes-Benz SLS AMG Electric Drive - powertrain overview [24]

The performance of Mercedes-Benz SLS AMG Coupe Electric Drive included $250 \mathrm{~km}$ of range (based on NEDC combined) and acceleration within $3.9 \mathrm{~s}$ from $0-100 \mathrm{~km} / \mathrm{h}$. The maximum vehicle speed was electronically restricted to $250 \mathrm{~km} / \mathrm{h}$. The vehicle also established a lap record of the Nurburgring for electric vehicle (EV) at $7.56 \mathrm{~min}$. The most powerful combustion version of this model, the MercedesBenz SLS AMG Coupe Black Series with $464 \mathrm{~kW}$ of peak power at $7400 \mathrm{rpm}$ and torque of $635 \mathrm{Nm}$ at $5500 \mathrm{rpm}$, performed $0-100 \mathrm{~km} / \mathrm{h}$ in $3.6 \mathrm{~s}$. That comparison shows respectable performance of electric model and makes it the most powerful and the fastest electric production vehicle. From the 2010 season onwards, the combustion version of the Mercedes-Benz SLS AMG also worked as the safety car during F1 races. Later in 2012 replaced by its successor Mercedes-AMG SLS GT [24].

\subsection{Mercedes-AMG Project ONE}

In 2012, Mercedes AMG High Performance Powertrains had already started its work on the new F1 Power Unit defined by FIA Formula One Technical Regulations. This technical specification became applicable from the 2014 season onwards and brought significant changes to F1 powertrains.

The Power Unit introduced in 2014 by Mercedes became an enormous success and started a three years of Mercedes domination within F1. Mercedes AMG Petronas Formula 1 team collected all Drivers Championship and Constructors Championship in three consecutive years: 2014, 2015 and 2016. Following that great achievement Mercedes-AMG and Mercedes AMG High Performance Powertrains are joining their efforts again to deliver the F1 technology based hypercar. This time Mercedes wants to go a step further and deliver, for the first time in the history of motoring, a production vehicle with a F1 powertrain. The
Mercedes-AMG Project ONE officially confirmed in 2016 at the Paris Motor Show.

The main idea of this vehicle is an ultimate hypercar with unaltered F1 hybrid technology with road approval. According to officially released information, the high performance F1 hybrid power unit is going to be accompanied with the purely electric and selective front axle. Overall peak power of the powertrain is going to exceed $735 \mathrm{~kW}$ (1000 hp). The general overview of the vehicle's powertrain is presented on the Fig. 13.

Mercedes-AMG Project ONE is going to be revealed on September 2017 at the International Motor Show in Frankfurt celebrating Mercedes-AMG's $50^{\text {th }}$ anniversary.

\section{Conclusions}

Despite Mercedes has started its F1 experience in 1950 s, the successful period did not last long and resulted with withdrawal from the motorsport. The Mercedes returned to the F1 after 40 years in 1990s. Initially, as an engine supplier, and later in 2010, as a constructor.

In 2006, FIA introduced first major amendments to the F1 Technical Regulations which included serious modifications to the powertrain system. Reduce of development costs of the engine and increase in its reliability started to play an important role in F1. An engine displacement has been reduced and its arrangement, together with the cylinder number were given for the first time.

From 2009, new regulations allowed F1 teams to use kinetic energy recovery systems. That created the first hybrid systems within F1 and shown the new directions of development.

The 2014 brought the most revolutionary changes in F1 history. The FIA made further steps into increasing of powertrain reliability and reduction of its development costs. General environmental considerations including reduction of $\mathrm{CO}_{2}$ were also included and resulted with the 


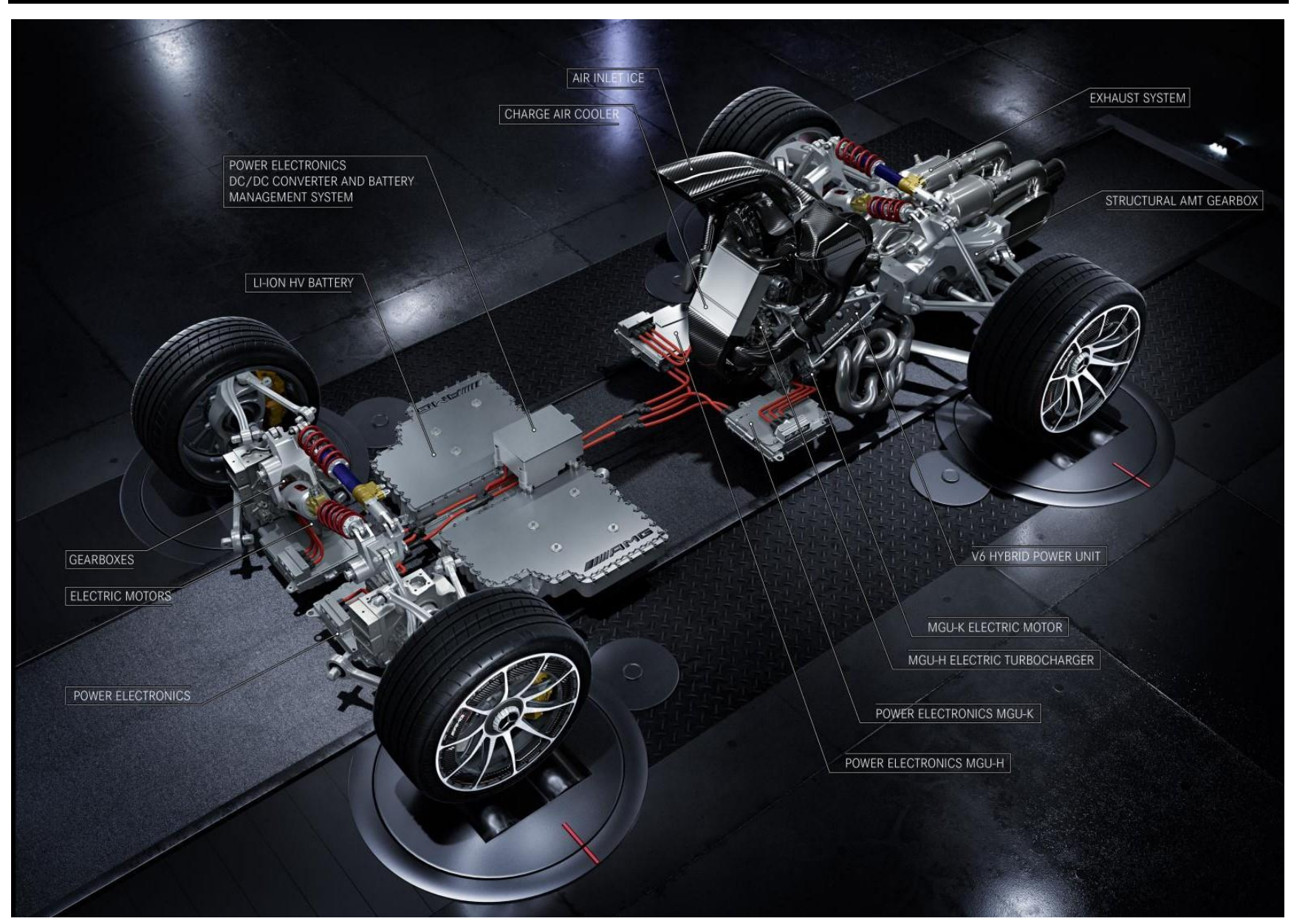

Fig. 13. Mercedes-AMG Project ONE - powertrain overview [24]

fuel restrictions. The new amendments included also higher relevance of F1 powertrain technology to the automotive world. The F1 high speed naturally aspirated engines ware changed into advanced, turbocharged hybrid power units.

The improvements introduced in 2014 to the F1 regulations returned significant achievements in several areas of powertrains performance. The fuel consumption and $\mathrm{CO}_{2}$ emission has been reduced due to the restrictions. The thermal efficiency of the ICE increased from about $27 \%$ in 2005 to about $47 \%$ in 2016 . The durability of the PU has also been enhanced from about $2500 \mathrm{~km}$ in 2013 to over $5000 \mathrm{~km}$ in 2015. The absence of KERS in F1 during 2010 motivated Mercedes to work on the F1 technology based vehicle and created the Mercedes-Benz SLS AMG Electric Drive. The expertise in the F1 hybrid systems allowed to develop electric vehicle which utilized F1 experience with Li-Ion batteries.
In 2015, Mercedes decided to make the next step and started its work on Mercedes-AMG Project ONE - vehicle which utilise entire F1 hybrid Power Unit.

Presented examples of technology transfer show that the F1 and the Automotive industry highly influence each other and provide satisfactory results. This allowed to formulate following observations:

1. The fuel restrictions to the F1 Power Units brought significant enhancement in thermal efficiency of the ICE which could be transferred to the Automotive industry.

2. The development of high performance hybrid systems might be shortly implemented in production vehicles.

3. The future FIA regulations within F1 might impose further reliability increase, reduction in fuel consumption and reduction or restrictions in exhaust gases emission.

\section{Nomenclature}

BMEP brake mean effective pressure

CE control electronics

CFRP carbon-fiber reinforced prastic

DLC diamond like carbon

ERS energy recovery system

ES energy store

EV electric vehicle

FIA Federation Internationale de l'Automobile
F1

ICE internal combustion engine

KERS kinetic energy recovery system

Li-Ion lithium-ion

MGU-H motor generator unit-heat

MGU-K motor generator unit-kinetic

MMC metal matrix composites

NEDC New European Driving Cycle 
PU power unit

PVRS pneumatic valve retuen system
$\mathrm{TC}$

VGT turbocharger

variable geometry turbocharger

\section{Bibliography}

[1] HEYWOOD, J.B. Internal Combustion Engine Fundamentals. McGraw-Hill, Inc. 1988.

[2] MERKISZ, J., PIELECHA, I. Układy mechaniczne pojazdów hybrydowych. Wydawnictwo Politechniki Poznańskiej. Poznań 2015.

[3] MERKISZ, J., PIELECHA, I. Układy elektryczne pojazdów hybrydowych. Wydawnictwo Politechniki Poznańskiej. Poznań 2015.

[4] MERKISZ, J., PIELECHA, I., MARKOWSKI, J. Wskaźniki pracy silników pojazdów wyczynowych. Combustion Engines. 2007, 4(131), 3-18.

[5] RYCHTER, W. Dzieje samochodu. Wydawnictwo Komunikacji i Łaczności. Warszawa 1979.

[6] STĘPIEN, Z. A new generation of F1 engines - hybrid power units. Combustion Engines. 2016, 167(4), 22-37.

[7] The F1s new power generation. F1 race technology. 2014

[8] The half way to impossible. Race Car Engineering. 2016.

[9] The last of the V8s. Race Car Engineering. 2013.

[10] The V8 F1 Engine. Formula One Technology. 2006, 38-43.

[11] 1988 Formula One Technical Regulations - Federation Internationale de l'Automobile.

Kalociński Tomasz, MEng. - Mechanical Engineer at Mercedes AMG High Performance Powertrains in Brixworth, UK.

e-mail: Tomasz.Kalocinski@mercedes-amg-hpp.com

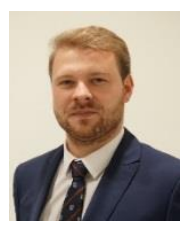

[12] 1994 Formula One Technical Regulations - Federation Internationale de l'Automobile

[13] 2005 Formula One Technical Regulations - Federation Internationale de l'Automobile

[14] 2006 Formula One Technical Regulations - Federation Internationale de l'Automobile

[15] 2007 Formula One Technical Regulations - Federation Internationale de l'Automobile

[16] 2008 Formula One Technical Regulations - Federation Internationale de l'Automobile

[17] 2009 Formula One Technical Regulations - Federation Internationale de l'Automobile

[18] 2013 Formula One Technical Regulations - Federation Internationale de l'Automobile

[19] 2014 Formula One Technical Regulations - Federation Internationale de l'Automobile

[20] 2015 Formula One Technical Regulations - Federation Internationale de l'Automobile

[21] 2016 Formula One Technical Regulations - Federation Internationale de l'Automobile

[22] www.mercedes-benz.com

[23] www.mercedesamgf1.com

[24] www.mercedes-amg.com

[25] www.mercedes-amg-hpp.com

Fuć Paweł, DSc., DEng. - Faculty of Machines and Transport at Poznan University of Technology.

e-mail:Pawel.Fuc@put.poznan.pl

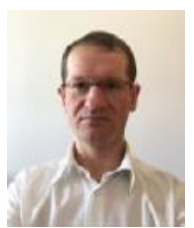

Rymaniak Łukasz, DEng. - Faculty of Machines and Transport at Poznan University of Technology.

e-mail: Lukasz.Rymaniak@put.poznan.pl

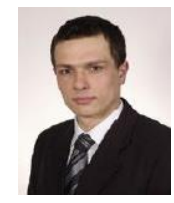

